\title{
SELF EFFICACY DAN KECEMASAN PEGAWAI NEGERI SIPIL MENGHADAPI PENSIUN
}

\author{
Christian \\ Clara Moningka \\ Program Studi Psikologi \\ Univeristas Bunda Mulia \\ Jalan Lodan Raya No. 2, Ancol \\ Jakarta Utara 14430 \\ chrishaha_3al@yahoo.co.id \\ claramoningka@gmail.com
}

\begin{abstract}
Someday, Ones must ended their working period. It is usually called retirement. Retirement is one of the frightening specter for the middle adult individuals. Fear of retirement shall cause anxiety. Overcoming anxiety can be different depending on the ability to cope with it (Cheung \& Sun, 2000 cited Pajares, 2006) and enhanced by the ability and competence to perform a task, goal, or to overcome strong resistance is called self-efficacy. (Bandura, in Baron \& Byrne, 2004). This study is a correlation research is aimed to understand the relationship between self-efficacy and anxiety facing retirement in the civil service civilians. The sample of the study was 87 people who will retire before the end of 2013 at the Ministry of $X$. This research is a quantitative study with two scales as a measurement tools, the Self Efficacy scale and Anxiety scale facing retirement adapted and developed by researchers using a Likert scale based components of self-efficacy (Bandura, 1986) and a form of anxiety facing retirement (Bucklew, 1980 From the analysis of the results obtained a negative relationship between self-efficacy with anxiety facing retirement in the civil service with a value of $r=-.409(p=.01)$. This means that self-efficacy is higher the lower the anxiety level civil servants who face pension, and conversely the lower the self-efficacy, the higher the anxiety level civil servants who will face retirement.
\end{abstract}

Keywords: self-efficacy, anxiety, retirement

\begin{abstract}
Abstrak
Pensiun merupakan salah satu momok yang menakutkan bagi para individu dewasa madya, apalagi bila individu tersebut sedang berada di puncak karirnya. Ketakutan akan pensiun tersebut menimbulkan kecemasan. Mengatasi kecemasan dapat berbeda tergantung pada kemampuan untuk mengatasi kecemasan tersebut (Cheung \& Sun dalam Pajares, 2006) dan ditingkatkan melalui kemampuan dan kompetensinya untuk melakukan sebuah tugas, mencapai tujuan, atau mengatasi hambatan yang kuat yang disebut self efficacy. (Bandura dalam Baron \& Byrne, 2004). Penelitian ini merupakan penelitian yang bersifat korelasional yang bertujuan untuk mengetahui hubungan antara self efficacy dengan kecemasan menghadapi pensiun pada pengawai negeri sipil. Adapun sampel dari penelitian ini adalah 87 orang yang akan menjelang pensiun hingga akhir tahun 2013
\end{abstract}


pada kementrian X. Penelitian ini merupakan penelitian kuantitatif dengan dua buah skala sebagai alat ukur, yaitu skala Self Efficacy dan skala Kecemasan menghadapi pensiun yang diadaptasi dan dikembangkan oleh peneliti dengan menggunakan skala Likert berdasarkan komponen self efficacy (Bandura, 1986) dan bentuk kecemasan menghadapi pensiun (Bucklew, 1980). Dari hasil analisa diperoleh diperoleh hubungan yang negatif antara self efficacy dengan kecemasan menghadapi pensiun pada pegawai negeri sipil dengan nilai $r=-.409(p=.01)$. Artinya adalah semakin tinggi self efficacy maka semakin rendah tingkat kecemasan pegawai negeri sipil yang akan menghadapi pensiun, dan sebaliknya semakin rendah self efficacy maka semakin tinggi tingkat kecemasan pegawai negeri sipil yang akan menghadapi pensiun.

Kata Kunci : self efficacy; kecemasan; pensiun

\section{PENDAHULUAN}

Pensiun adalah peran baru dalam hidup seseorang yang berhenti dari pekerjaan formal dan tidak bekerja lagi serta mengalami perubahan ekonomi berupa pendapatan yang jauh berkurang dari sebelumnya (Turner \& Helms dalam Purnamawati, 2007).

Menurut penelitian (Dinsi, Setiati, Yuliasari, 2006) pihak yang paling takut menghadapi masa pensiun adalah Pegawai Negeri Sipil (PNS). Kecemasan dan stres psikologis saat pensiun lebih banyak dialami oleh individu yang bekerja sebagai PNS. Individu yang merasa cemas baik secara psikis maupun biologis, dalam dirinya akan terjadi gangguan antisipasi akan harapan di masa yang akan datang. Kecemasan adalah perasaan campuran berisi ketakutan dan keprihatinan mengenai rasa-rasa mendatang tanpa sebab khusus untuk ketakutan tersebut (Chaplin, 2000). Hal senada juga dikatakan dalam Bandura (1997) bahwa individu yang mengalami kecemasan menunjukkan ketakutan dan perilaku menghindar yang sering mengganggu kehidupan mereka. Kecemasan PNS Ini dikarenakan dari segi ekonomi pendapatan yang jauh dibandingkan dengan pendapatan pegawai lainnya.

Dalam memasuki masa pensiun, seseorang akan kehilangan peran sosialnya di masyarakat, penyesuaian psikologis, penyesuaian akan kondisi keuangan, kehilangan kontak sosial (Turner \& Helms, 1987 dalam Putri, 2010), kehilangan harga diri karena kehilangan jabatan, kehilangan hubungan dengan kelompok eksklusif dan kehilangan perasaan berarti dalam suatu kelompok tertentu (Turner \& Helms, 1983 dalam Handayani, 2008). Seseorang yang telah habis masa purna tugasnya atau pensiun cenderung akan mengalami depresi, mental shock atau goncangan kejiwaan yang dikenal dengan istilah post power syndrome yaitu gejala kejiwaan yang kurang stabil dan muncul ketika seseorang turun dari jabatan yang dimiliki sebelumnya. Gejala ini ditandai dengan wajah yang tampak jauh lebih tua, pemurung, sakit-sakitan, lemah mudah tersinggung, merasa tidak berharga, melakukan pola-pola kekerasan yang menunjukkan kemarahan baik di rumah maupun di tempat lain (Rini, 2001). Akan tetapi, dari sekian banyak penyebab di atas, faktor utama yang mendasari seorang yang cenderung cemas menghadapi pensiun adalah oleh karena perasaan kehilangan (Hadi, 2004).

Untuk menangani masalah di atas, antara satu individu dengan individu yang lainnya berbeda, tergantung pada penilaian diri individu terhadap kemampuan yang dimilikinya yang disebut dengan self efficacy (Sarafino, 1994). Baron dan Byrne (2004) mengemukakan self efficacy merupakan penilaian individu terhadap kemampuan atau kompetensinya untuk melakukan suatu tugas, mencapai suatu tujuan, dan menghasilkan sesuatu. Selain itu, self efficacy juga sebagai perasaan individu terhadap kecukupan, efisiensi, dan kemampuan individu dalam mengatasi kehidupan (Schultz, 1994 dalam Anwar, 2009). 
Keyakinan efficacy dikatakan dapat mempengaruhi individu dalam mengintepretasikan suatu kejadian. Individu yang memiliki self efficacy yang rendah dengan mudah akan yakin bahwa usaha yang mereka yang lakukan dalam menghadapi tantangan yang sulit akan sia-sia, sehingga mereka cenderung untuk mengalami gejala negatif yang datang. Sedangkan individu yang memiliki self efficacy yang tinggi akan cenderung untuk melihat tantangan sebagai sesuatu yang dapat diatasi yang diberikan oleh kompetensi dan upaya yang cukup (Bandura dalam Avey, Luthans \& Jensen, 2009 dalam Pujiati, 2010). Ketika individu menghadapi suatu tekanan, dalam hal ini kecemasan menghadapi pensiun, keyakinan individu terhadap kemampuan mereka (self efficacy) akan mempengaruhi cara individu dalam bereaksi terhadap situasi yang menekan (Bandura, 1997 dalam Baron \& Byrne, 2004). Individu seringkali kurang memiliki self efficacy dalam situasi interpersonal yang disebabkan oleh kurangnya kemampuan sosial (Morris, 1995 dalam Baron \& Byrne, 2004); atribusi yang tidak tepat, tidak memadainya karakter diri, dan tidak bersedia untuk mengambil inisiatif dalam persahabatan (Fan \& Mark, 1998 dalam Baron \& Byrne, 2004).

Tiap individu memiliki karakteristik seperti kemampuan, kepercayaan pribadi, harapan, kebutuhan, kegigihan dalam menghadapi rintangan dan pengalaman masa lalunya (Sambodo, 2012). Self Efficacy cenderung konsisten sepanjang waktu, tetapi bukan berarti tidak berubah. Umpan balik positif terhadap kemampuan seseorang dapat meningkatkan self efficacy (Bandura, 1986 dalam Baron \& Byrne, 2004). Dalam menghadapi masa pensiun, keyakinan atas kemampuan diri sendiri dalam mengatasi tekanan akan mempengaruhi kesiapan individu dalam menghadapi pensiun.

Penelitian ini akan dilakukan pada Pegawai Negeri Sipil di Kementerian Pertahanan RI. Kementerian Pertahanan RI adalah salah satu Kementerian yang memiliki pegawai bukan hanya pegawai negeri sipil melainkan terdapat TNI, dimana pada level dan golongan yang sama, mulai dari gaji pokok hingga uang lauk pauk antara PNS dengan TNI adalah berbeda besarannya sehingga tentu terdapat perbedaan dari segi penghasilan walaupun golongan kerja dan masa kerja yang sama.

\section{Tujuan Penelitian}

Untuk mengetahui hubungan antara self efficacy dengan kecemasan dalam menghadapi pensiun bagi pegawai negeri sipil di Kementerian Pertahanan RI.

\section{Tinjauan Teori}

\section{Self Efficacy}

\section{a. Definisi Self Efficacy}

Self Efficacy adalah evaluasi seseorang terhadap kemampuan atau kompetensinya untuk melakukan sebuah tugas, mencapai tujuan, atau mengatasi hambatan (Bandura, 1977 dalam Baron \& Byrne, 2004). Woolfolk (2009) juga menyebutkan bahwa self efficacy adalah kepercayaan mengenai kompetensi personal dalam sebuah situasi khusus. Performa fisik (Courneya \& McAuley, 1993; Duncan \& McElnoy, dalam Adair, 1998), mencapai kesuksesan (Sanna \& Pusecker dalam Hennessy, Elisabeth, Nicole, 2006), performa dalam pekerjaan (Ivancevich, Konopaske, Michael, 2007), dan kemampuan untuk mengatasi kecemasan dan depresi (Cheung \& Sun, dalam Pajares, Urdan, 2006), ditingkatkan melalui perasaan yang kuat akan self efficacy. 
Pada umumnya orang akan bertindak untuk mencapai tujuan, jika individu merasa akan mendapat hasil dari tindakannya tersebut. Jika ia tidak yakin bahwa tindakannya akan berhasil, maka ia merasa imbalan untuk tindakannya cenderung tidak ada atau relative hanya sedikit (Bandura dalam Baron \& Byrne, 2004). Makin tinggi self efficacy seseorang, makin ia merasa yakin bahwa ia mampu merampungkan tindakannya; sebaliknya makin rendah self efficacynya, makin ia merasa tidak mampu menuntaskan tindakannya (Bandura, 1997, dalam Setiadarma, 2005). Ketika menemui kesulitan, individu yang meragukan kemampuannya akan mengurangi usaha dan menyerah, sementara individu yang memiliki self efficacy yang kuat akan memunculkan usaha yang lebih besar untuk menguasai tantangan (Bandura, dalam Assaat, 2007). Dapat disimpulkan, bahwa self efficacy merupakan kemampuan seseorang dalam kompetensinya untuk mencapai suatu tujuan, serta kemampuan dalam mengatasi suatu hambatan dan kecemasan dalam situasi khusus yang dihadapinya.

\section{b. Komponen Self Efficacy}

Bandura (1986) mengatakan bahwa perbedaan self efficacy pada setiap individu terletak pada tiga komponen, yaitu komponen magnitude, generality, dan strength. Masing-masing komponen memiliki implikasi yang penting di dalam performansi, yang dapat diuraikan sebagai berikut;

\section{- Komponen Magnitude}

Komponen magnitude (tingkat kesulitan tugas) adalah masalah yang berkaitan dengan derajat kesulitan tugas individu (Bandura, 1986). Komponen ini berimplikasi pada pemilihan perilaku yang akan dicoba individu berdasar ekspektasi efikasi pada tingkat kesulitan tugas. Individu akan berupaya melakukan tugas tertentu yang ia persepsikan dapat dilaksanakannya dan ia akan menghindari situasi dan perilaku yang ia persepsikan di luar batas kemampuannya.

\section{- Komponen Generality}

Komponen generality adalah hal yang berkaitan mencakup luas bidang tingkah laku di mana individu merasa yakin terhadap kemampuannya. Individu dapat merasa yakin terhadap kemampuan dirinya, tergantung pada pemahaman kemampuan dirinya yang terbatas pada suatu aktivitas dan situasi tertentu atau pada serangkaian aktivitas dan situasi yang lebih luas dan bervariasi.

\section{- Komponen Strength}

Komponen strength adalah berkaitan dengan kekuatan pada keyakinan individu atas kemampuannya. Pengharapan yang kuat dan mantap pada individu akan mendorong untuk gigih dalam berupaya mencapai tujuan, walaupun mungkin belum memiliki pengalaman-pengalaman yang menunjang. Sebaliknya pengharapan yang lemah dan ragu-ragu akan kemampuan diri akan mudah digoyahkan oleh pengalaman-pengalaman yang tidak menunjang.

\section{Kecemasan}

\section{a. Definisi Kecemasan}

Hilgard (dalam Atkinson, 1996) menjelaskan bahwa kecemasan adalah emosi yang tidak menyenangkan, yang ditandai dengan istilah-istilah seperti kekhawatiran, 
keprihatinan dan rasa takut yang kadang kita alami dalam tingkat yang berbeda-beda. Kecemasan merupakan suatu respon terhadap situasi yang penuh dengan tekanan. Sementara, stres dapat didefinisikan sebagai suatu persepsi ancaman terhadap suatu harapan yang mencetuskan cemas. Hasilnya adalah bekerja untuk melegakan tingkah laku (Rawlins dalam Prasetyo, Saputro, 2012).

Freud (dalam Semium, 2006) mengatakan bahwa kecemasan adalah suatu perasaan afektif yang tidak menyenangkan yang disertai dengan sensasi fisik yang mengikutkan orang terhadap bahaya yang akan datang.

\section{b. Tingkat Kecemasan}

Simtom-simtom somatis yang dapat menunjukkan ciri-ciri kecemasan menurut Stern (1964) adalah muntah-muntah, diare, denyut jantung yang bertambah keras, seringkali buang air, nafas sesak disertai tremor pada otot. Kartono (1981) menyebutkan bahwa kecemasan ditandai dengan emosi yang tidak stabil, sangat mudah tersinggung dan marah, sering dalam keadaan excited atau gempar gelisah.

Menurut Bucklew (1980), para ahli membagi bentuk kecemasan itu dalam dua tingkat, yaitu:

\section{- Tingkat Psikologis}

Kecemasan yang berwujud sebagai gejala-gejala kejiwaan, seperti tegang, bingung, khawatir, sukar berkonsentrasi, perasaan tidak menentu dan sebagainya.

\section{- Tingkat Fisiologis}

Kecemasan sudah mempengaruhi atau terwujud pada gejala fisik, terutama pada fungsi sistem saraf pusat, misalnya: tidak dapat tidur, jantung berdebar-debar, keluar keringat dingin berlebihan, sering gemetar dan perut mual dan sebagainya.

\section{Definisi Pensiun}

Pensiun merupakan akhir dari seseorang melakukan pekerjaannya. Beverly (dalam Hurlock, 1994) berpendapat bahwa pensiun seringkali dianggap sebagai kenyataan yang tidak menyenangkan sehingga menjelang masa tiba sebagian orang sudah merasa cemas karena tidak tahu kehidupan macam apa yang akan dihadapinya kelak. Parnes dan Nessel (dalam Corsini, 1987) mengatakan bahwa pensiun adalah suatu kondisi dimana individu tersebut telah berhenti bekerja pada suatu pekerjaan yang biasa dilakukan. Batasan yang lebih jelas dan lengkap oleh Corsini (1987) mengatakan bahwa pensiun adalah proses pemisahan seorang individu dari pekerjaannya, dimana dalam menjalankan perannya seseorang digaji.

Dengan kata lain masa pensiun mempengaruhi aktivitas seseorang, dari situasi kerja ke situasi di luar pekerjaan. Sedangkan berdasarkan pandangan psikologi perkembangan, pensiun dapat dijelaskan sebagai suatu masa transisi ke pola hidup baru, ataupun merupakan akhir pola hidup (Schawrz dalam Hurlock, 1980)

\section{METODE}

Rancangan penelitian yang digunakan adalah penelitian kuantitatif. Populasi penelitian ini adalah pegawai negeri sipil di Kementerian X yang maksimal satu tahun sampai satu tahun setengah yaitu hingga 2013 sebelum menjelang pensiun. Adapun populasi pegawai negeri yang akan menjelang 
pensiun dari Juli 2012 hingga Desember 2013 adalah sebanyak 87 orang. Subjek penelitian diambil dengan menggunakan teknik sampling jenuh. Sampling jenuh adalah teknik penentuan sampel bila semua anggota populasi digunakan sebagai sampel, istilah lainnya adalah sensus, dimana semua anggota populasi dijadikan sampel (Sugiyono, 2007).

Instrumen penelitian menggunakan dua kuesioner yaitu kuesioner self efficacy berdasarkan tiga komponen, yaitu komponen magnitude, generality, dan strength (Bandura, 1986) dan kuesioner kecemasan yang diukur melalui aspek fisiologis dan psikologis menurut Bucklew (1980) yang diadaptasi dari dua kuesioner, kuesioner self efficacy diadaptasi dan dimodifikasi dari Kurniawan (2010). Kemudian kuesioner kecemasan diadaptasi dan dimodifikasi dari Sofia (2007).Teknik analisis yang digunakan adalah teknik analisis uji korelasi.

\section{ANALISIS \& HASIL}

\section{a. Reliabilitas dan Validitas}

Berdasarkan hasil pengujian, alat ukur self efficacy memiliki nilai reliabilitas sebesar 0,846 dengan rentang validitas $0,264-0,623$, dan sementara untuk alat ukur kecemasan diperoleh nilai reliabilitas sebesar 0, 891 dengan rentang 0,238-0,632.

Tabel 1.Hasil Realibilitas Self Efficacy dan Kecemasan

\begin{tabular}{|c|c|c|c|}
\hline $\begin{array}{c}\text { Cronbach's AlphaSelf } \\
\text { Efficacy }\end{array}$ & N of Items & $\begin{array}{c}\text { Cronbach's Alpha } \\
\text { Kecemasan }\end{array}$ & N of Items \\
\hline .846 & 23 & .891 & 21 \\
\hline
\end{tabular}

\section{b. Uji Normalitas}

Berdasarkan nilai signifikansi dari uji normalitas (one sample K-S) skala self efficacy dan kecemasan, diketahui bahwa nilai signifikansi diatas .05, di mana untuk variabel self efficacy sebesar .397 dan variabel kecemasan sebesar 1.279 sehingga data terdistribusi normal.

Tabel 2.Hasil Uji Normalitas

\begin{tabular}{|l|l|c|c|}
\hline \multicolumn{3}{|c|}{ One-Sample Kolmogorov-Smirnov Test } \\
\hline \multirow{2}{*}{ N } & & SelfEfficacy & Kecemasan \\
\hline \multirow{2}{*}{ Normal Parameters } & & 87 & 87 \\
\cline { 2 - 4 } & Mean & 91.83 & 44.20 \\
\cline { 2 - 4 } & Std. Deviation & 8.597 & 10.607 \\
\hline Most Extreme Differences & Absolute & .043 & .136 \\
\cline { 2 - 4 } & Positive & .038 & .136 \\
\cline { 2 - 4 } & Negative & -.043 & -.044 \\
\hline Kolmogorov-Smirnov Z & & .397 & .080 \\
\hline Asymp. Sig. (2-tailed) & .997 & \\
\hline a. Test distribution is Normal. & & \\
\hline b. Calculated from data. & & \\
\hline
\end{tabular}




\section{c. Uji Korelasi}

Hasil pengujian menunjukkan korelasi antara variabel self efficacy dengan kecemasan menghadapi pensiun adalah hubungan yang negatif dengan Pearson Correlation -.409 $(r=-0,409)$ di mana $\mathrm{r}<0$ yang berarti telah terjadi hubungan linier yang negatif.

Tabel 3.Hasil Uji Korelasi

\begin{tabular}{|l|l|c|c|}
\hline \multicolumn{3}{|c|}{ Correlations } \\
\hline \multirow{3}{*}{ V1 } & Pearson Correlation & V1 & V2 \\
\cline { 2 - 4 } & Sig. (2-tailed) & 1 & $-.409^{* *}$ \\
\cline { 2 - 4 } & $\mathrm{N}$ & & .000 \\
\hline \multirow{3}{*}{ V2 } & Pearson Correlation & $-.409^{* *}$ & 87 \\
\cline { 2 - 4 } & Sig. (2-tailed) & .000 & 1 \\
\cline { 2 - 4 } & N & 87 & 87 \\
\hline \multirow{2}{*}{$* *$ Correlation is significant at the 0.01 level (2-tailed). } \\
\hline
\end{tabular}

\section{DISKUSI}

Hasil penelitian ini menunjukan terdapat hubungan linear yang negatif namun tidak kuat. Terdapat hubungan linear yang negatif dimana kecemasan rendah dan self efficacy tinggi dikarenakan menurut Longhurst seseorang yang siap menghadapi pensiun dengan konsep diri yang positif, punya penilaian positif mengenai dirinya cenderung ia akan lebih bahagia (Eliana, 2003). Dengan pengalaman dari pensiunan-pensiunan sebelumnya para pegawai negeri sipil Kementerian X menyadari bahwa pensiun adalah sesuatu yang perlu dipersiakan, sehingga para pegawai negeri sipil yang akan menjelang pensiun mempersiapkan masa pensiun mereka baik dari kesehatan, kondisi finansial dan persiapan mental psikologis. Para pegawai negeri sipil Kementerian X memiliki penilaian positif akan dirinya bahwa setelah mereka pensiun, mereka tidaklah kehilangan segalanya, mereka tetap memperoleh gaji pensiun, tunjangan kesehatan, bila gaji pegawai negeri sipil naik gaji pensiun juga akan disesuaikan naik walaupun besaran nominal dan fasilitas yang disediakan tidaklah sama nilainya seperti ketika mereka masih menjadi pegawai negeri sipil di Kementerian Pertahanan.

Dengan mempersiapkan pensiun sebaik-baiknya sebelum mereka pensiun, pensiun bukanlah suatu hal yang paling menakutkan bagi mereka, dengan penilaian positif dan persiapan akan pensiun, akan membuat self confidence cenderung menguat. Adapun self confidence sendiri adalah keyakinan yang dimiliki seseorang bahwa dirinya mampu berperilaku seperti yang dibutuhkan untuk memperoleh hasil seperti yang diharapkan (Sari, 1995). Kepercayaan diri ini ditujukan pada keyakinan bahwa seseorang dapat menyebabkan sesuatu terjadi sesuai harapan-harapannya.

Seorang yang siap menghadapi pensiun adalah mereka yang menetapkan tujuan pensiun, perencanaan pensiun yang efektif dimulai dengan mengidentifikasikan dan memprioritaskan tujuan pensiun (Sinar Harapan, 2003 dalam Danny, 2011).

Hasil penelitian sebelumnya di Universitas Michigan yang meneliti para pensiunan menunjukkan bahwa sebanyak 75 persen pekerja yang membuat persiapan sebelumnya akan menikmati masa pensiunnya dibanding 25 persen lainnya yang tidak membuat persiapan (Sutarto \& Cokro, 2008). Seorang memiliki kecemasan yang rendah ketika akan menghadapi pensiun dikarenakan individu 
telah memperoleh pelajaran dari pengalaman banyak orang, dimana diambil nilai-nilai yang dapat diambil sebagai pembelajaran dari kejadian masa lalu. Seluruh program pensiun di hari tua seseorang sangat dan sangat dipengaruhi persiapan dan kesiapan di awal jauh sebelum mereka pensiun (Sutarto \& Cokro, 2008).

Sutarto dan Cokro (2008) dalam bukunya juga mengatakan, jika hal tersebut tertata rapi, hal itu sudah merupakan setengah jalan keberhasilan memperoleh apa yang diinginkan ketika pensiun dan menapaki usia lanjut. Meskipun setiap individu memiliki persiapan dan kesiapan pensiun yang berbeda, mereka memiliki kesamaan mendasar yang merupakan kebutuhan utama, yaitu kesiapan materi finansial seperti ketersediaan bekal pendukung berupa tabungan, asuransi, simpanan aset dan kegiatan usaha selain penghasilan bulanan pensiun.

Dengan begitu, seorang yang memiliki self efficacy tinggi akan memiliki kecemasan yang rendah meskipun self efficacy bukanlah satu-satunya faktor yang mempengaruhi tingkat kecemasan seseorang yang akan menghadapi pensiun.

\section{SIMPULAN \& SARAN}

Berdasarkan hasil dari penelitian yang telah dilakukan, diperoleh kesimpulan yaitu terdapat hubungan negatif yang signifikan antara self efficacy dengan kecemasan menghadapi pensiun pada pegawai negeri sipil di Kementerian X. Hal ini mengandunng pengertian bahwa semakin tinggi self efficacy, maka semakin rendah tingkat kecemasan menjelang pensiun pada pegawai negeri sipil di Kementerian X.

Terdapat hubungan yang negatif namun tidak kuat yaitu sebesar .167 (16,7\%) saja self efficacy mempengaruhi kecemasan pada pegawai negeri sipil di Kementerian Pertahanan RI yang akan menghadapi pensiun dikarenakan pegawai negeri sipil yang akan menjelang pensiun memiliki penilaian yang positif bahwa setelah pensiun mereka tidak kehilangan segalanya, mereka tetap memperoleh gaji pensiun, tunjangan kesehatan walaupun tidak sama besaran seperti ketika masih menjadi pegawai negeri sipil. Dengan penilaian yang positif para pegawai negeri sipil mempersiapkan masa pensiun dengan sebaik-baiknya dengan penuh optimis bahwasanya pensiun bukanlah suatu yang menakutkan bila dipersiapkan dengan baik.

Berikut adalah saran berdasarkan hasil studi ini;

1. Saran Teoretis

Peneliti Selanjutnya

- Untuk peneliti berikutnya, diharapkan dapat memperhatikan adanya variabel-variabel kontrol seperti tingkat pendidikan, jumlah anak, dan lain sebagainya yang mempengaruhi self efficacy maupun kecemasan menghadapi pensiun, dan juga karena pada penelitian ini, hal tersebut belum menjadi bagian dari penelitian ini.

- Menggunakan cakupan subyek yang lebih luas untuk dibandingkan hasilnya seperti dengan kementerian lain atau dalam satu lingkup wilayah maupun antar wilayah.

2. Saran Praktis

a. Pegawai Negeri Sipil (PNS)

Bila dibandingkan dengan pegawai negeri sipil dulu dengan sekarang, pensiun bukanlah sesuatu yang menakutkan bila dipersiapkan dengan baik. Dengan pengalaman dan wawasan penelitian ini menjadikan tambahan wawasan bagi para pegawai negeri sipil untuk lebih mempersiapkan diri baik secara fisik maupun psikologis. 
Mempersiapkan kegiatan baru setelah pensiun adalah salah satu perencanaan yang baik, kegiatan menekuni bidang usaha bisnis, kegiatan sosial, pekerjaan baru yang lebih cocok dengan usia setelah pensiun, dan lain sebagainya. Dengan begitu setelah pensiun, para pegawai negeri sipil terus dapat beraktivitas menekuni bidang usaha, kegiatan sosial, dan pekerjaan baru yang telah mereka siapkan sebelum mereka pensiun dan tidak kaget akan kehidupan yang tiba-tiba mendadak berubah tidak ada kesibukan apapun setelah pensiun karena telah bertahun-tahun menjalani rutinitas secara tiba-tiba tidak ada aktivitas atau kegiatan apapun yang bias dilakukan oleh karena persiapan yang kurang baik sebelum pensiun.

Ketika mempersiapkan hal tersebut, kita telah menghindari diri kita baik fisik maupun psikis dari hal-hal yang bersifat yang bisa membangkitkan emosi, stres, diri rendah, dan pikiran negatif.

b. Instansi Pemerintahan Kementerian Pertahanan RI

Instansi memberikan kebijakan tertentu pada pegawai negeri sipil yang akan menghadapi pensiun dengan memberikan waktu kerja yang fleksibel, seperti tiga bulan menjelang pensiun, diberikan kebijakan jam pulang lebih awal dariketentuan, atau jam masuk lebih longgar dari ketentuan atau hari masuk kerja yang dikurangi porsinya misalnya seminggu tiga hari masuk kerja. Hal ini untuk membiasakan para pegawai negeri sipil yang akan menghadapi pensiun untuk beradaptasi dengan kehidupan setelah pensiun nanti yang perlahan-lahan lepas dari rutinitas yang telah bertahun-tahun melekat pada diri pegawai negeri sipil tersebut.

Instansi juga perlu memberikan kursus kepada para pegawai negeri sipil yang akan menghadapi pensiun dalam berwirausaha, sebagai modal mereka menjelang pensiun dan memberikan mereka wawasan dan pengetahuan untuk berwirausaha setelah pensiun nanti dan juga turut berpartisipasi membantu mereka dalam mewujudkannya.

\section{DAFTAR PUSTAKA}

Adair, J. G,. Belanger. D,. Kenneth. L. D. (1998). Advances In Psychological Science: Social, Personal and Cultural Aspects.East Sussex: Psychology Press.

Anwar, A.I.D. (2009). Hubungan Antara Self Efficacy Dengan Kecemasan Berbicara Di Depan Umum Pada Mahasiswa Fakultas Psikologi Universitas Sumatera Utara. Skripsi Fakultas Psikologi USU.

Assaat, I. (2007). Persepsi Atas Program Akselerasi Dan Stres Akademik. Jurnal Provitae Volume 3. Jakarta: Fakultas Psikologi Untar.

Atkinson, R.L., Atkinson, R.C., Hilgard, E.R. (1996). Pengantar Psikologi.. Jakarta: Erlangga.

Bandura, A. (1986). Social Foundations Of Thought And Action; A Social Cognitive Theory. New Jersey: Prentice-Hall.

Baron, R,. \& Byrne. (2004). Psikologi Sosial. Jakarta: Erlangga.

Bucklew, J. (1980). Paradigma for Psychopatology. A Contribution to Case History Analysis. New York: J.B. Lippenscott Company.

Chaplin, J. P. (2000). Kamus Lengkap Psikologi. Penerjemah Kartini Kartono. Jakarta: Raja Grafindo Persada. 
Corsini, R. J. (1987). The Concise Encyclopedia of Psychology. Canada : John Willey \& Sons.

Dinsi, V,. Setiati, E., Yuliasari, E. (2006). Ketika Pensiun Tiba. Jakarta : Wijayata Media Utama.

Eliana, Rika. (2003). Konsep Diri Pensiunan. Program Studi Psikologi, Fakultas Kedokteran Universitas Sumatera Utara.

Hadi, P. (2004). Depresi dan Solusinya. Yogyakarta: Tugu Publisher.

Handayani, Y. (2008). Gambaran Post Power Syndrome pada Pegawai Negeri Sipil yang Mengalami Masa Pensiun. Skripsi Fakultas Psikologi Universitas Gunadarma.

Hennessy, D. A., Elizabeth. L. M,. \& Nicole. M. (2006) "The Effects of Fatal Vision Goggles on Drinking and Driving Intentions in College Students. "Journal of Drug Education.

Hurlock. (1980) Psikologi Perkembangan. Jakarta: Erlangga

Hurlock. (1994). Psikologi Perkembangan; Suatu Pendekatan Sepanjang Rentang Kehidupan. Edisi V. Jakarta: Erlangga.

Ivancevich, J. M,. Konopaske, R,. Michael, T. M. (2007). Perilaku dan Manajemen Organisasi. Jilid 7. (Terjemahan). Jakarta: Erlangga

Kartono, K. (1981). Patologi Sosial 3 Gangguan-Gangguan Kejiwaan. Jakarta: Rajawali.

Kurniawan, R. (2011). Pengaruh self-efficacy dan motivasi belajar mahasiswa terhadap kemandirian belajar mata kuliah analisis laporan keuangan pada mahasiswa Program studi pendidikan akuntansi angkatan 2008 Fakultas ilmu sosial dan ekonomi Universitas Negeri Yogyakarta. Skripsi Fakultas Ilmu Sosial dan Ekonomi. Yogyakarta : Universitas Negeri Yogyakarta

Pajares, F,. \& Urdan, T. C. (2006). Self-Efficacy Beliefs of Adolescent. A Volume in Adolescene and Education. United States of America: Information Age Publishing.Inc.

Pujiati, NA. (2010). Hubungan Antara Self Efficacy Dengan Kemandirian Belajar Siswa; studi terhadap siswa kelas VIII SMP Negeri 2 Rajapolah Kabupaten Tasikmalaya. Skripsi Universitas Pendidikan Indonesia.

Purnamawati, N. D. (2007). Gambaran Psychological. Skripsi Fakultas Psikologi. Depok: Universitas Indonesia.

Putri, N. E. (2010). Hubungan Konsep Diri Dengan Kecemasan Menghadapi Pensiun (Studi Korelasional Terhadap Karyawan Pt Badak Ngl, Bontang, Kalimantan Timur). Skripsi Jurusan Psikologi Fakultas FIP Universitas Pendidikan Indonesia.

Sarafino, E. (1994).Heath Psychology 2nd. New York: John Wiley \& Sons.

Sari, N.P. (1995). Peran Dukungan Sosial Terhadap Kepribadian Diri Pada Remaja. Jakarta: Rajawali.

Semium, Y. (2006). Teori Kepribadian dan Terapi Psikoanalitik Freud. Yogyakarta: Kanisius.

Setiadarma, M. P. (2005). Self-Handicaping Dan Prokrastinasi Dalam Proses Pendidikan. Jurnal Provitae Volume 1. Jakarta: Fakultas Psikologi Untar.

Sofia, K. (2007). Pengaruh Konsep Diri Terhadap Tingkat Kecemasan Menghadapi Masa Pensiun Pada Pegawai Negeri Sipil Dinas Perindustrian, Perdagangan Dan Penanaman Modal Kabupaten Sumenep. Skripsi Fakultas Psikologi. Universitas Islam Negeri Malang

Stern, P. (1964). The Abnormal Person and His World. London. D van Nostrand Co.

Sugiyono. (2007). Metode Penelitian Bisnis. Bandung: Alfabeta.

Suryabrata, S. (2008). Psikologi Kepribadian. Jakarta: PT. Raja Grafindo Persada. 
Sutarto, J,T,. \& Cokro, I. (2008. Pensiun Bukan Akhir Segalanya. Jakarta: Gramedia Pustaka Utama.

Woolfolk, A. (2009). Educational Psychology; Active Learning Edition. Yogyakarta: Pustaka Belajar.

\section{Internet:}

Bandura, A. (1986). Self-Efficacy (Efikasi Diri). Retrieved 28 April 2012 from http;//treepjkr.multiply. com/reviews/item/22.

Bandura, A. (1997). Self-Efficacy (Efikasi Diri). Diambil pada tanggal 28 April 2012. Retrieved; http;// treepjkr.multiply.com/reviews/item/22 12 April 2010.

Baron, R,. \&Byrne. (1997). Self Efficacy (Efikasi Diri). Diambil pada tanggal 28 April 2012. Retrieved; http;//treepjkr.multiply.com/reviews/item/22.

Danny. (2011) Siapkan Kebutuhan Masa Pensiun Sekarang. (Rencanakan Hidup Anda, Hidupkan Rencana Anda dari Koran Sinar Harapan, 2003). Diunduh 17 Maret 2012 from http:// payonefortwo.blogspot.com/2011/11/siapkan-kebutuhan-masa-pensiun-sekarang.html.

Prasetyo, B. E,. Saputro, D. K. (2012). Pengaruh Psikologi Trauma dan Cemas Yang Ditimbulkan Pada Seseorang Yang Mengalami Patah Tulang (Fraktur) Pada Bagian Tungkai Bawah. Diambil pada tanggal 10 Juni 2012. Retrieved; http://bambangekoprasetyo.blog.esaunggul.ac.id/.

Rini, J. F. (2001). Pensiun dan Pengaruhnya. Diambil pada tanggal 28 April 2012. Retrieved; http;// www.psikologi.com/usia/pensiun.htm.

Sambodo, A.T. (2012). Perilaku Individu. Retrieved 17 Maret 2012 from http://aji-t.blogspot. com/2012/03/perilaku-individu.html. 
